\title{
Implementasi Simple Additive Weighting Penentuan Prioritas Penanganan Sumber Air Bersih
}

\author{
Evi Yulianingsih ${ }^{[1]}$, Nia Oktaviani ${ }^{[2]}$, Usman Ependi ${ }^{[3]}{ }^{*}$ \\ Program Studi Sistem Informasi, Fakultas Ilmu Komputer ${ }^{[1], \text { [2], [3] }}$ \\ Universitas Bina Darma \\ Palembang, Indonesia \\ evi_yulianingsih@binadarma.ac.id ${ }^{[1]}$,niaoktaviani@binadarma.ac.id ${ }^{[2]}$,u.ependi@binadarma.ac.id ${ }^{[3]^{*}}$
}

\begin{abstract}
Clean water is the need of every human being, for that the necessity of clean water is a priority for the government in providing services. The current problem is the lack of clean water that has not been evenly distributed due to government limitations. For that reason, in providing services, it must be according to priority in order to have a broad impact on the community. For this reason, in this research the development of an information system can be used to assist in determining priorities in handling clean water sources. In the development process the waterfall method is used while the determination of priorities uses simple additive weighting. The results showed that the simple additive weighting method can provide a clear value in determining the priority of clean water handling. This condition can be seen from the existing process in the information system, which starts from weighting, filling the survey value to simple additive weighting calculations. besides that, the information system can run well in accordance with the expected proven by the results of testing using black box testing to get the test results received. This condition is proven by the function of the information system that produces the calculation correctly in accordance with the provisions of the SAW.
\end{abstract}

Keywords - Simple Additive Weighting, Waterfall, Clean Water

Abstrak-Air bersih adalah kebutuhan setiap manusia, untuk itu kebutuhan air bersih merupakan prioritas bagi pemerintah dalam memberikan layanan. Masalah saat ini adalah kurangnya air bersih yang belum merata karena keterbatasan pemerintah. Oleh Sebab itu, dalam memberikan layanan, harus sesuai prioritas agar berdampak luas pada masyarakat. Untuk itu, dalam penelitian ini dilakukan pengembangan sistem informasi yang dapat digunakan untuk membantu dalam menentukan prioritas dalam penanganan sumber air bersih. Dalam proses pengembangan metode air terjun digunakan sementara penentuan prioritas menggunakan pembobotan aditif sederhana. Hasil penelitian menunjukkan bahwa metode pembobotan aditif sederhana dapat memberikan nilai yang jelas dalam menentukan prioritas penanganan air bersih. Kondisi ini dapat dilihat dari proses yang ada dalam sistem informasi, yang dimulai dari pembobotan, pengisian nilai survei hingga perhitungan pembobotan aditif sederhana. Selain itu, sistem informasi dapat berjalan dengan baik sesuai dengan yang diharapkan dibuktikan dengan hasil pengujian menggunakan pengujian black box untuk mendapatkan hasil pengujian yang diterima. Kondisi ini dibuktikan dengan fungsi sistem informasi yang menghasilkan perhitungan dengan benar sesuai dengan ketentuan SAW.

Kata Kunci-Simple Additive Weighting, Waterfall, Air Bersih

\section{PENDAHULUAN}

Sesuai dengan Undang Undang Dasar 1945 yang terdapat pada pasal 33 ayat 2 menyatakan bahwa "bumi dan air dan kekayaan alam yang terkandung di dalamnya dikuasai oleh negara dan dipergunakan untuk sebesar-besar kemakmuran rakyat" [1]. Dengan demikian penjaminan kegunaan sumber daya alam terutama sumber daya air menjadi keharusan bagi penyelengara negara terutama pemerintah. salah satu usaha nyata pemerintah yaitu adanya instasnsi yang membidangi masalah pengairan yaitu Dinas PU Cipta Karya dan Tata Ruang. Dimana dinas ini terdapat disetiap kabupaten/kota walaupun dengan nama yang berbeda namun dengan fungsi yang sama.

Salah satu dinas tersebut yaitu Dinas PU Cipta Karya dan Tata Ruang yang ada di Kabupaten Musi Banyuasin. Dinas ini memiliki peran sebagai pelaksana bidang PU dan pengelolaan sumber daya air yang ada di lingkungan Kabupaten Musi Banyuasin. Pengelolaan sumber daya air tidak hanya terkait dengan pengelolaan kebutuhan pertanian, pertambangan namun juga berkaitan dengan pengelolaan kebutuhan air bersih untuk rumah tangga yang meliputi wilayah kota dan desa.

Air bersih merupakan salah satu kebutuhan dasar bagi masyarakat. Kebutuhan tersebut bersifat berkesinambungan sehingga pelayanan penyediaan air bersih menjadi keharusan [2]. Kondisi tersebut tentunya terjadi disetiap daerah khususnya di Kabupaten Musi Banyuasin. Untuk memenuhi kebutuhan air bersih kadang kala tidak sebanding dengan ketersediaan air bersih itu sendiri sehingga tidak terpenuhinya permintaan air bersih. Selain itu juga dapat disebabkan oleh penigkatan permukinan penduduk atau berkembangnya sebuah kawasan serta menigkatnya perekonomian masyarakat itu sendiri. 
Sesuai dengan kondisi tersebut maka timbul beberapa permasalahan di sisi pemerintah sebagai penyedia air bersih. Diantara permasalahan tersebut yaitu: pertama, banyaknya permintaan masyarakat. Kedua, terbatasnya sumber daya dalam memenuhi kebutuhan ari bersih, dan ketiga penentuan prioritas pemasangan air bersih. Permasalahan yang timbul tersebut tentunya harus diberikan solusi bagi pemerintah, terutama dalam penentuan keputusan. salah satu solusi yang dapat digunakan yaitu membuat mekanisme penentuan prioritas dalam membuat fasilitas air bersih utuk masyarakat. Proses atau mekanisme yang dapat diberikan yaitu melalui sistem informasi yang dapat membantu pemerintah dalam menentukan atau mengambil kebijakan tentang prioritas pemasangan air bersih dari semua usulan yang diberikan oleh masyarakat.

Penentuan atau penyeleksian tersebut dapat dilakukan dengan menerapkan berbagai metode pada sistem informasi untuk mengambil keputusan atau penunjang keputusan. Salah satu metode tersebut yaitu metode simple additive weighting $(S A W)$. Metode simple additive weighting $(S A W)$ merupakan metode yang menekankan pada pembobotan dari semua atribut yang menjadi penilaian [3]. Simple additive weighting $(S A W)$ memiliki konsep dengan cara melakukan penjumlahan terhadap atribut atau indikator dalam penilaian untuk menentukan rangking [4]. Metode simple additive weighting $(S A W)$ juga melakukan proses normalisasi terhadap matrik kedalam skala tertentu untuk dilakukan perbandingan dalam penentuan rating atau perangkingan [5]. Hasil penilaian dalam bentuk rating atau perangkingan didasari oleh nilai kritertia atau pembobotan sesuai ketentuan [6].

Penelitian terkait dengan metode simple additive weighting $(S A W)$ digunakan untuk membuat sistem informasi pendukung keputusan. Diantara penelitian tersebut dilakukan untuk menentukan seleksi penerima beasiswa. Kriteria penilaian yang digunakan sebanyak lima kriteria yaitu indek prestasi komulatif, penghasilan orang tua, prestasi siswa, organisasi yang diikuti dan tanggungan orang tua [7]. Penelitian lain juga berkaitan dengan sistem pendukung keputusan penerimaan beasiswa, dimana di dalam penelitian ini yang menjadi kriteria penilaian yaitu penghasilan orang tua, semester, tanggungan, saudara kandung dan nilai [8]. Kajian lain juga berkaitan dengan simple additive weighting (SAW) dilakukan untuk menentukan jurusan pada sekolah tingkat menengah atas [9]. Selain dari penentuan beasiswa dan jurusan metode simple additive weighting ( $S A W$ ) digunakan untuk menentukan siswa bermasalah pada sebuah sekolah. Di dalam kajian tersebut yang menjadi kriteria yaitu kepatuhan, nilai rapot, kehadiran dan jiwa sosial [10]. Metode simple additive weighting (SAW) juga dapat digunakan untuk membuat sistem informasi pendukung keputusan dalam melakukan evaluasi keputusan dalam proses "evaluasi alternatif pemilihan pemenang pengadaan asset" [11].

Sesuai dengan kondisi yang terjadi berkaitan dengan penentuan prioritas penyediaan air bersih pada Kabupaten Musi Banyuasin maka salah satu solusi yang dapat dilakukan yaitu menggunakan sistem informasi. Untuk itu dalam penelitian akan dilakukan pengembangan sistem informasi dengan menerapkan metode simple additive weighting (SAW) sebagai metode untuk menentukan prioritas dalam membuat fasilitas air bersih. Penentuan prioritas tersebut berdasarkan kriteria yang terdiri dari jumlah penduduk, kebutuhan air, debit air, jarak pipa irigasi, beda tinggi, gesekan dan tekanan.

\section{METODOLOGI PENELITIAN}

Untuk melakukan penelitian sebagai upaya penyelesaian malasah maka metode yang digunakan didalam penelitian ini dapat dijelaskan seabgai berikut

\section{A. Metode Penelitian}

Dalam melakukan peneltian implementasi simple additive weighting dalam penentuan prioritas penanganan sumber air bersih ini metode yang digunakan untuk menjelaskan hasil peneltian menggunakan teknik atau metode deskriptif. Dalam banya penelitian dijelaskan bahwa metode ini merupakan metode yang digunakan untuk menjelasakan fakta dan penomena sebuah objek yang diteliti berdasarkan pandangan peneliti [12]. Dapat juga dikatakan bahwa metode penelitian dekkriptif merupakan paparan sebuah kedaan fakta yang diteliti berdasarkan perspektif peneliti [13].

\section{B. Metode Pengembangan Sistem Informasi}

Untuk menghasilkan sistem informasi yang sesuai dengan kebtuhan dalam pemencahan masalah penentuan prioritas atau rangking pembangaunan penyediaan ari bersih, maka dalam proses pengembangan diguakan sebuah metode pengembangan. Metode pengembangan yang digunakan yaitu metode pengembangan kasik yaitu waterfall. Metode ini telah mengalami beberapa perkembangan dalam langkah-langkah pengembangan. Tahapan metode waterfall terdapat dua jenis yaitu pertama: requirement analysis, design, implementation, testing, dan maintenance [14]. Kedua yaitu: communication, planning, modeling, construction, dan deployment [15]. Untuk itu dalam proses pengembangan sistem informasi penentuan prioritas air bersih dengan mengimplementasi simple additive weighting (SAW) digunakan proses pengembangan cara kedua. Proses pengembangan dengan cara kedua ini seperti yang diperlihatkan pada Gambar 1 .

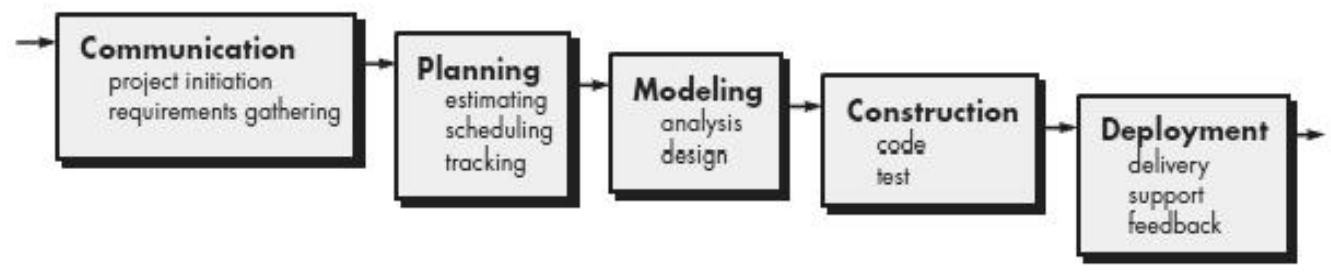

Gambar 1. Proses Pengembangan Waterfall [16] 
Sesuai Gambar 1 merupakan proses pengembangan sistem informasi maka dapat dijelaskan pekerjaan atau aktivitas yang dilakukan untuk setiap tahapan pengembagan sebagai beriktu [15]:

- Communication, aktivitas dan pekerjaan yang dilakukan pada tahapan communication yaitu analisis kebutuhan awal sesuai dengan project initiation. Pada tahapan ini terdapat aktivitas pengumpulan data yang akan digunakan dalam proses pengembangan sistem informasi.

- Planning, aktivitas dan pekerjaan yang dilakukan pada tahapan planning yaitu membuat perencanaan dalam proses pengembangan sistem infomrasi. Perancangan tersebut meliputi tiga aspek yaitu estimating, scheduling dan tracking.

- Modeling, aktivitas dan pekerjaan yang dilakukan pada tahapan modeling yaitu membuat sebuah model analisis dan perancangan antarmuka dari sistem infomrasi yang akan dihasilkan. Namun dalan penelitian ini hanya akan dibuat dari hasil model anaslsis menggunakan unified modeling language (UML).

- Construction, aktivitas dan pekerjaan yang dilakukan pada construction yaitu proes penterjemahan hasil modeling kedalam bentuk coding. Selain itu juga dilakukan implementasi simple additive weighting (SAW) sebagai metode dalam menentukan prioritas penyediaan air bersih.

- Deployment, tahapan deployment merupakan proses terakhir yang dilakukan. Pada tahapan ini dilakukan pengiriman (delivery) sistem informasi kepada pemakai.

\section{Metode Pengujian}

Metode pengujian merupakan metode yang digunakan untuk menguji sistem informasi yang dihasilkan. Metode pengujian yang digunakan yaitu metode black box testing. Metode ini merupakan metode yang melihat sistem informasi dari sudut pandang input dan output. Metode ini juga sering dikenal dengan metode pengujian yang melihat fungsional sebuah sistem informasi, dalam artian melihat apakah komponen sistem informasi yang dihasilkan telah berjalan sesuai dengan yang diharapkan ataukah sebaliknya [17].

\section{Pemodelan Sistem Informasi}

Pemodelan sistem informasi merupakan proses penterjemahan kebutuhan sistem informasi dari kebutuhan sistem informasi. Dimana dalam implementasi simple additive weighting dalam penentuan prioritas penanganan sumber air bersih kebutuhan yang ingin dicapai yaitu bagaimana menentukan prioritas berdasarkan kriteria yang telah ditentukan. Untuk itu di dalam pemodelan sistem informasi ini dibuat dua jenis pemodelan sebagai gambaran bagaimana sistem informasi yang akan dihasilkan. Dalam melakukan pemodelan ini digunakan dua diagram untuk menggambarkan bagaimana sistem informasi yang akan dihasilkan. Dua diagram tersebut yaitu use case diagram dan activity diagram. Use case diagram digunakan untuk menggambarkan tingkah laku atau behavior dari sistem informasi sedangkan activity diagram digunakan untuk menggambarkan interaksi dari sistem informasi.

Use case diagram digunakan dalam pemodelan sistem informasi ini sebagai alat untuk menggambarkan peran pengguna yang berinteraksi dengan sistem informasi. Selain itu juga use case diagram digunakan untuk melihat komponen fungsional sistem informasi yang dapat diakses oleh pengguna [18]. Dalam pengembagnan sistema informasi penentuan prioritas sumber air bersih ini dapat diketahui bahwa pengguna dapat melakukan berbagai aktivitas yaitu: memasukkan data lokasi, informasi alternatif kriteria, informasi normalisasi, informasi hasil normalisasi dan keputusan pembuatan sumber air bersih. Kondisi tersebut seperti yang digambarkan pada use case diagram yang terlihat pada Gambar 2.

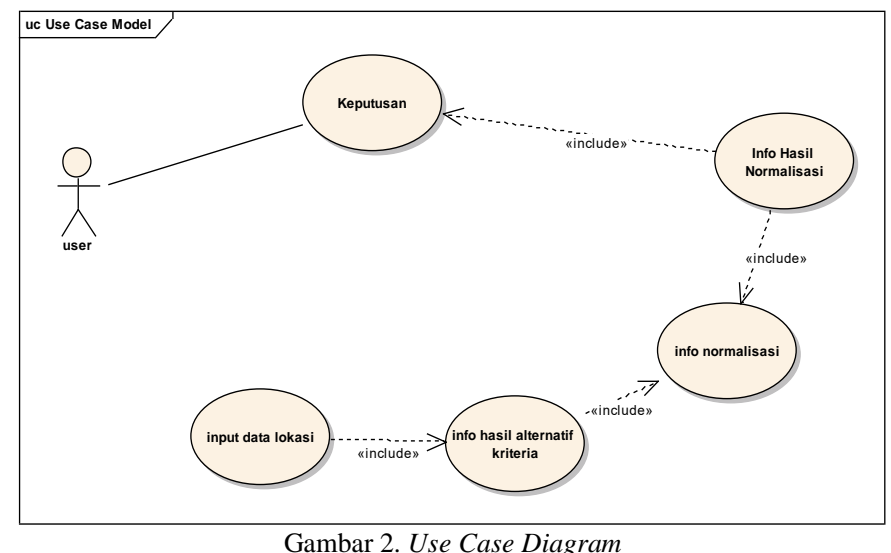

Activity Diagram merupakan diagram yang dapat digunakan untuk melihat alur kerja, logika prosedur dan prosis bisnis dari sebuah sistem informasi. Activity diagram juga dapat menunjukkan alir sebuah proes dalam system informasi. Namun memiliki perbedaan yang mendasar dengan flowchart. Perbedaan tersebut terlihat dari bagaimana activity diagram dalam memperlihatkan behavior dari sistem informasi [19].

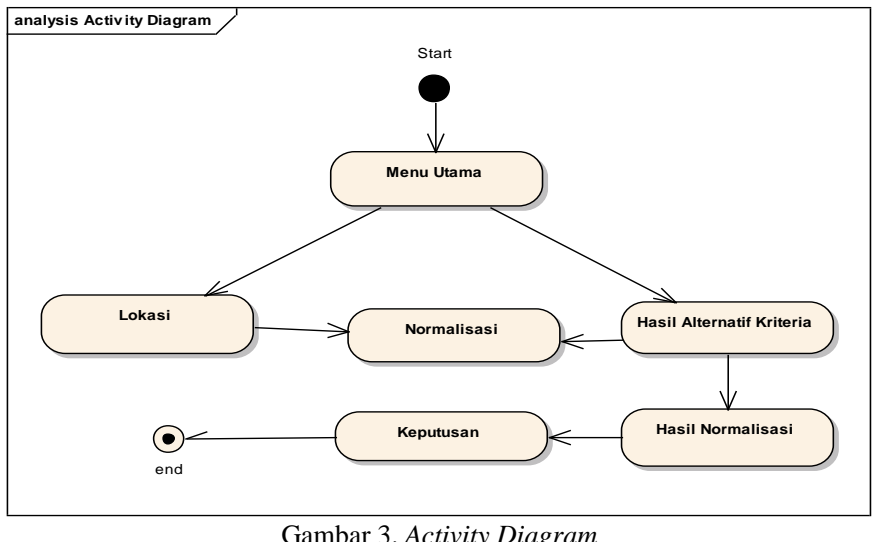

Untuk itu dalam implementasi metode simple additive weighting $(S A W)$ untuk penentuan prioritas penanganan sumber air bersih activity diagram seperti yang diperlihatkan pada Gambar 3. Dari Gambar 3 dapat diketahui bahwa semua 
komponen sistem informasi berjalan melalui menu utama. Proses yang dilakukan dalam system informasi dimulai dari penentuan lokasi dan dapat juga melalui alternative kriteria. Selanjutnya dilakukan normalisasi. Kemudian dilanjutkan dengan hasil normalisasi dan terakhir mendapatkan keputusan.

\section{HASIL DAN PEMBAHASAN}

\section{A. Implementasi Sistem Informasi}

Dalam melakukan implementasi sistem informasi yang dapat digunakan untuk menentukan prioritas penyedian air bersih maka terdapat kriteria dalam melakukan penilaian. Kriteria penilaian tersebut meliputi $\mathrm{C} 1$ untuk jumlah penduduk, C2 untuk kebutuhan air, C3 untuk debit air, C4 untuk jarak pipanisasi, C5 untuk beda tinggi, C6 untuk gesekan dan C7 untuk tekanan. Kriteria penilaian tersebut seperti yang diperlihatkan pada Tabel 1.

TABEL I

KRITERIA PENILAIAN

\begin{tabular}{|c|c|}
\hline \multicolumn{2}{|c|}{ KRITERIA PENILAIAN } \\
\hline Kriteria & Keterangan \\
\hline C1 & Jumlah Penduduk \\
\hline C2 & Kebutuhan Air \\
\hline C3 & Debit Air \\
\hline C4 & Jarak Pipanisasi \\
\hline C5 & Beda Tinggi \\
\hline C6 & Gesekan \\
\hline C7 & Tekanan \\
\hline
\end{tabular}

Untuk menentukan penilaian digunakan bilangan fuzzy yang terdiri dari lima kriteria yaitu 5 berarti sangat tinggi, 4 berarti tinggi, 3 berarti cukup, 2 berarti rendah, dan 1 berarti sangat rendah. Penggunaan nilai fuzzy tersebut untuk memudahkan perhitungan implementasi simple additive weighting (SAW) agar penentuan prioritas dapat dilakukan dengan mudah. Pada Tabel 2 dapat dilihat kriteria bilangan fuzzy yang digunakan.

TABEL II

KRITERIA BILANGAN

\begin{tabular}{|c|c|}
\hline Bilagan Fuzzy & Nilai \\
\hline Sangat Tinggi & 5 \\
\hline Tinggi & 4 \\
\hline Cukup & 3 \\
\hline Rendah & 2 \\
\hline Sangat Rendah & 1 \\
\hline
\end{tabular}

Setelah mengetahui kriteria dan kriteria bilangan yang digunakan untuk melakukan perhitungan prioritas penyediaan sumber air bersih maka selanjutnya adalah melakukan penentuan bobot kriteria pada sistem informasi yang dihasilkan. Seperti yang terlihat pada Gambar 4 merupakan form yang dapat digunakan untuk menentukan bobot kriteria tersebut. Pada Gambar 4 dapat dilihat penentuan bobot kriteria yaitu sangat tinggi yang berarti nilai yang digunakan yaitu angka 5. Namun dapat juga dibuat dengan nilai yang berbeda tergantung dengan prioritas yang diinginkan seperti tinggi dengan nilai 4 , cukup dengan nilai 3 , rendah dengan nilai 2 dan sangat rendah dengan nilai 1 .

\section{[ Bobot Kriteria] [ Data Hasil Survey] [Hasil Perhitungan SAW] [ Logout]}

\begin{tabular}{ll} 
Bobot Kriteria & \\
\hline Jumlah Penduduk Air & $:$ Sangat Tinggi $v$ \\
Kebutuhan Air & $:$ Sangat Tinggi $v$ \\
Debit Air & Sangat Tinggi $v$ \\
Jarak Pipanisasi & $:$ Sangat Tinggi $v$ \\
Beda Tinggi & $:$ Sangat Tinggi $v$ \\
Gesekan & $:$ Sangat Tinggi $v$ \\
Tekanan & $:$ Sangat Tinggi $v$ \\
\hline & SIMPAN
\end{tabular}

Gambar 4. Bobot Kriteria Penilaian

Setelah mengetahui nilai bobot kriteria yang digunakan maka selanjutnya dapat melakukan pengisian hasil survey. Pengisian hasil survey didapat dari survey lapangan yang dilakukan pihak Dinas PU Cipta Karya dan Tata Ruang yang ada di Kabupaten Musi Banyuasin. Survey yang dilakukan dengan cara melakukan kunjungan langsung ke kecamatankecamatan yang ada di Kabupaten Musi Banyuasin. Selain itu juga dapat dilakukan dengan cara mewakilkan kepada pihak kecamtan untuk melakukan survey lapangan terhadap daerah atau pedesaan yang ada di setiap kecamtan. Nilai survey yang dimasukkan pada sistem informasi ini berupa nilai keadaan umum untuk setiap kecamatan. Untuk memasukkan data hasil survey pada sistem informasi dimulai dari memilih kode kecamatan dan akan otomatis tampil nama kecamatan yang dimaksud. Setelah nama kecamatan muncul maka pengguna dapat dapat memasukkan data nilai hasil survey berupa jumlah penduduk, kebutuhan air, debit mata air, jarak pipanisasi, beda tinggi, gaya gesekan dan tinggi tekanan. Proses pengisian tersebut seperti yang diperlihatkan pada Gambar 5.

[ Bobot Kriteria ] [ Data Hasil Survey] [Hasil Perhitungan SAW] [ Logout ]

SUMBER MATA AI

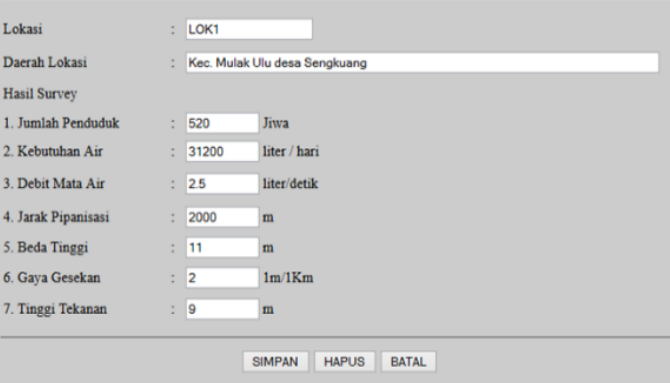

Gambar 5. Hasil Survey Sumber Air Lapangan 
Untuk melihat hasil perhitungan setelah selesai memaukkan data hasil survey maka dapat dilakukan pada menu hasil perhitungan SAW. Menu ini akan menampilan secara keseluruhan hasil perhitungan dari forim yang ditampilkan daman bentuk atau berupa tabel hasil survey seperti yang diperlihatkan pada Gambar 6. Hasil pengisian ditampilan dikelompokan berdasarkan nama tempat dan kriteria penilaian yaitu $\mathrm{C} 1$ untuk jumlah penduduk, $\mathrm{C} 2$ untuk kebutuhan air, C3 untuk debit air, C4 untuk jarak pipanisasi, C5 untuk beda tinggi, C6 untuk gesekan dan C7 untuk tekanan.

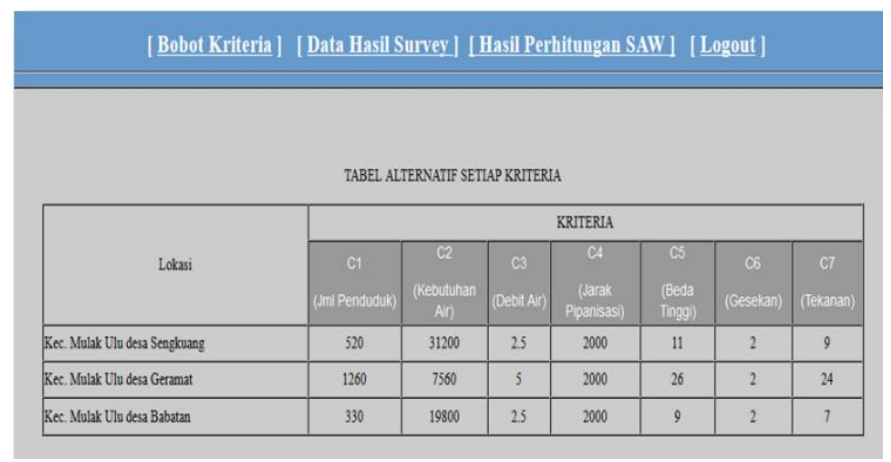

Gambar 6. Alternatif Setiap Kriteria

Hasil masukkan seperti yang diperlihatkan pada Gambar 6 dilakukan konversi nilai berdasarkan kriteria bilangan fuzzy yaitu dari 1 sampai dengan 5 . 5 berarti sangat tinggi, 4 berarti tinggi, 3 berarti cukup, 2 berarti rendah, dan 1 berarti sangat rendah. Salah satu hasil konversi bilangan tersebut seperti yang diperlihatkan pada Gambar 7.

\begin{tabular}{|l|l|l|l|l|l|l|l|}
\hline Bobobt $(\mathrm{W})=$ & 5 & 5 & 4 & 2 & 2 & 2 & 2 \\
\hline
\end{tabular}

\section{Gambar 7. Normalisasi}

Setelah melakukan konversi hasil survey selanjutnya dilakukan perhitungan sesuai dengan ketentuan simple additive weighting (SAW).

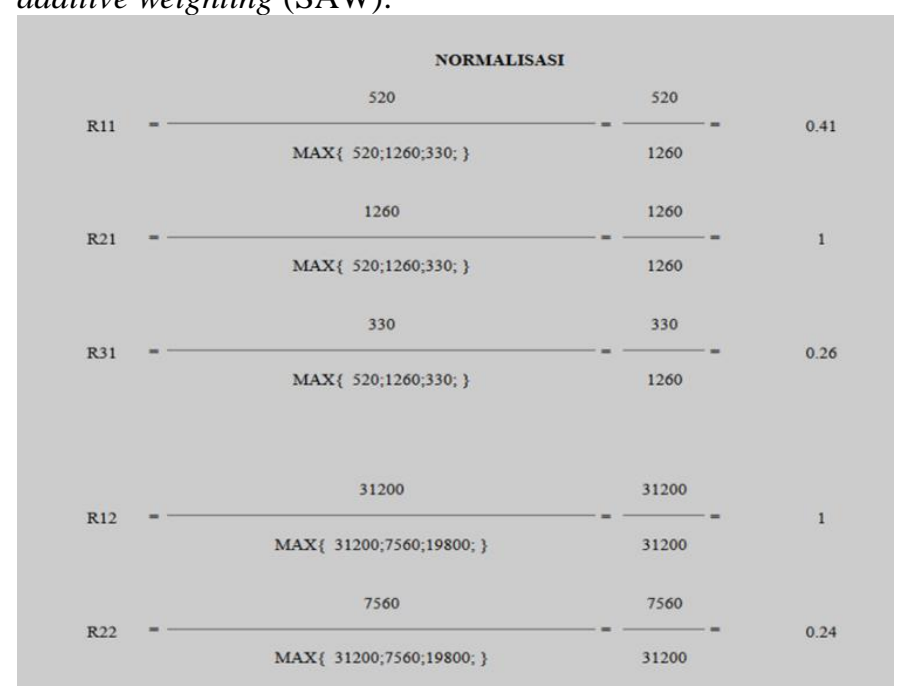

Gambar 8. Perhitungan Normalisasi
Perhitungan dilakukan untuk menentukan perangkingan atau pemeringkatan prioritas dalam penanganan sumber air bersih. Proses perhitungan tersebut seperti yang diperlihatkan pada Gambar 8. Pada Gambar 8 dapat dilihat perhitungan dilakukan untuk setiap daerah yang dimasukkan dan berdasarkan kriteria penialaian.

Proses terakhir dari simple additive weighting (SAW) adalah menentukan rangking dari setiap nilai yang diproses. Untuk menentukan rangkin maka dilakukan jumlah untuk setiap komponen kriteria penialaian yaitu mulai dari C1 untuk jumlah penduduk, C2 untuk kebutuhan air, C3 untuk debit air, C4 untuk jarak pipanisasi, C5 untuk beda tinggi, C6 untuk gesekan dan C7 untuk tekanan. Dari penjumlahan tersebut maka didapat nilai untuk masing-masing daerah yang dimasukkan. Semakin tinggi nilai yang didapat maka menjadi prioritas utama dalam pengembangan atau pengadaan sumber air. Hasil perhitungan dalam penentuan prioritas penanganan sumber air bersih seperti yang diperlihatkan pada Gambar 9.

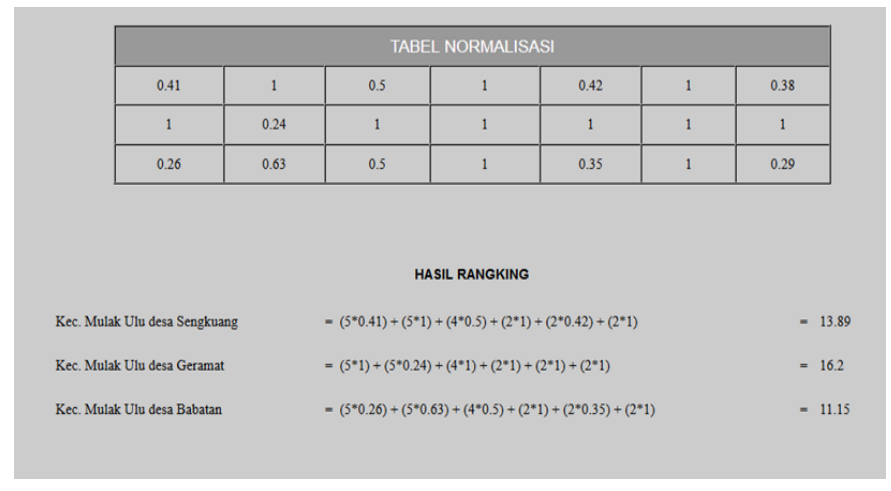

Gambar 9. Hasil Rangking

\section{B. Pengujian Sistem Informasi}

Pengujian sistem informasi merupakan proses validasi dan verifikasi sistem informasi. Pengujian juga dilakukan untuk melihat apakah fungsional sistem informasi telah berjalan dengan baik ataukah sebaliknya. Dalam melakukan pengujian sistem informasi digunakan teknik pengujian black box testing. Dimana pengujian ini lakukan untuk melihat fungsional dari sistem informasi yang dihasilkan. Untuk itu berikut dapat dilihat hasil pengujian sistem informasi penentuan prioritas penanganan sumber air menggunakan metode simple additive weighting (SAW).

TABEL III

HASIL PENGUJIAN

\begin{tabular}{|c|c|c|c|}
\hline Komponen & \multicolumn{2}{|c|}{ Pengamatan } & $\begin{array}{c}\text { Hasil } \\
\text { Pengujian }\end{array}$ \\
\hline \multirow{4}{*}{$\begin{array}{l}\text { Bobot } \\
\text { Kriteria }\end{array}$} & \multicolumn{2}{|c|}{ 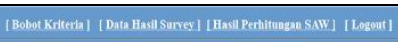 } & \multirow{4}{*}{$\begin{array}{l}\text { Berfungsi } \\
\text { (Dterima) }\end{array}$} \\
\hline & \multicolumn{2}{|l|}{ 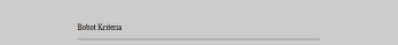 } & \\
\hline & 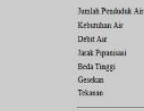 & 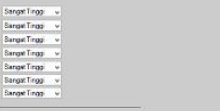 & \\
\hline & & guan & \\
\hline
\end{tabular}




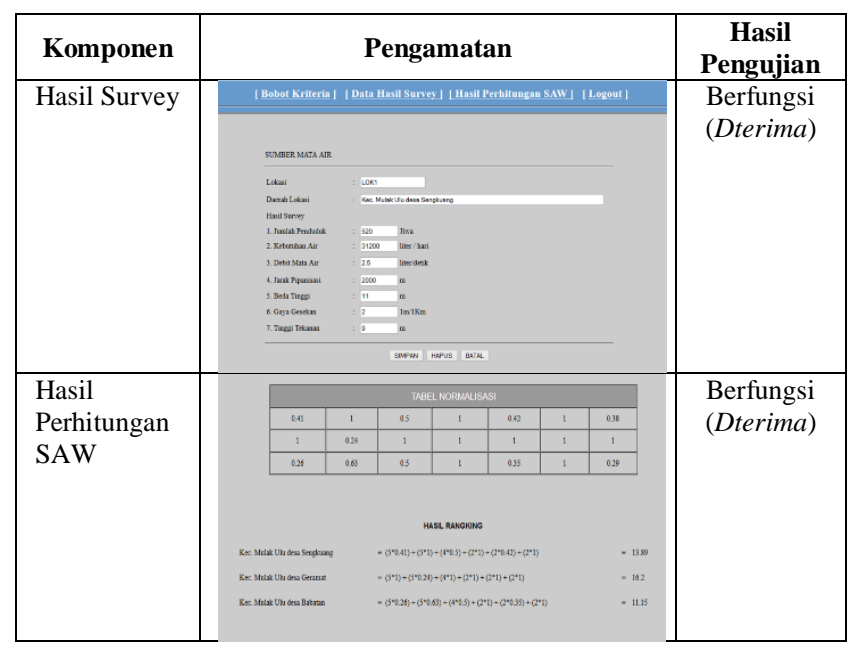

\section{PENUTUP}

Sesuai dengan proses penelitian yang telah dilakukan yaitu implementasi simple additive weighting dalam penentuan prioritas penanganan sumber air bersih maka dapat disimpulkan bahwa untuk menentukan perangkingan dalam menentukan prioritas digunakan kriteria penilaian dan nilai bobot agar nilai pengukuran dapat dilakukan perhitungan dengan mudah. Selain itu juga simple additive weighting dapat diimplementasikan pada sistem informasi dengan sangat sederhana dan mendapatkan hasil yang jelas. Untuk melihat sistem informasi yang dihasilkan sesuai dengan keinginan juga dapat dilakukan dengan melakukan pengujian seperti black box testing. Dari hasil pengujian menunjukkan bahwa semua fungsional sistem informasi berjalan dengan baik dan menghasilkan output atau nilai yang benar.

\section{UCAPAN TERIMA KASIH}

Terima kasih diucapkan kepada redaksi Jurnal Sisfokom yang telah meluangkan waktu dan tenada untuk melakukan review, editing dan publishing artikel ini. Terima kasih juga kami sampaikan kepada Universitas Bina Darma yang telah membiaya penelitian ini hingga terlaksana dengan baik.

\section{REFERENSI}

[1] E. Ruslina, "Makna Pasal 33 Undang-Undang Dasar 1945 dalam Pembangunan Hukum Ekonomi Indonesia," J. Konstitusi, vol. 9, no. 1, p. 109449, 2012.

[2] D. Kusumawardani, "Valuasi Ekonomi Air Bersih di Kota Surabaya," J. Ekon. dan Bisnis Airlangga (JEBA)| J. Econ. Bus. Airlangga, vol. 21, no. 3, 2011.

[3] R. Marbun and I. Gunawan, "Sistem Pendukung Keputusan Perankingan Data Konsumen Penumpang Kereta Api Dengan Menggunakan Metode Simple Additive Weighting Di PT. KAI," Juripol, vol. 2, no. 1, pp. 15-25, 2018.

[4] I. Gunawan, S. Sutanto, and I. Yunita, "DECISION SUPPORT
SYSTEM PENENTUAN PEGAWAI TERBAIK DENGAN METODE SAW (STUDI KASUS UNIVERSITAS BANTEN JAYA)," J. Ilm. Sains dan Teknol., vol. 2, no. 2, pp. 14-26, 2018.

[5] A. S. Putra, D. R. Aryanti, and I. Hartati, "Metode SAW (Simple Additive Weighting) sebagai Sistem Pendukung Keputusan Guru Berprestasi (Studi Kasus: SMK Global Surya)," in Prosiding Seminar Nasional Darmajaya, 2018, vol. 1, no. 1, pp. 85-97.

[6] M. Munir, F. Marisa, and D. Purnomo, "SISTEM PENUNJANG KEPUTUSAN DALAM PENGKLASIFIKASIAN MAHASISWA PENERIMA BEASISWA DENGAN METODE SIMPLE ADDITIVE WEIGHTING DI UNIVERSITAS WIDYAGAMA MALANG," $J$. SPIRIT, vol. 10, no. 2, 2018.

[7] W. Supriyanti, "Rancang bangun aplikasi sistem pendukung keputusan penerima beasiswa dengan metode SAW," Creat. Inf. Technol. J., vol. 1, no. 1, pp. 67-75, 2013.

[8] M. Muslihudin and D. Hartini, "Perancangan Sistem Pendukung Pengambilan Keputusan Untuk Penerimaan Beasiswa Di SMA PGRI 1 Talang Padang Dengan Model Fuzzy Multiple Attribute Menggunakan Metode Simple Additive Weighting (SAW)," J. TAM (Technology Accept. Model., vol. 4, pp. 34-40, 2017.

[9] M. Elistri, J. Wahyudi, and R. Supardi, "Penerapan metode saw dalam sistem pendukung keputusan pemilihan jurusan pada Sekolah Menengah Atas Negeri 8 Seluma," J. Media Infotama, vol. 10, no. 2, 2014.

[10] H. T. Sihotang and M. S. Siboro, "Aplikasi Sistem Pendukung Keputusan Penentuan Siswa Bermasalah Menggunakan Metode Saw Pada Sekolah Smp Swasta Mulia Pratama Medan,” J. Inform. Pelita Nusant., vol. 1, no. 1, 2016.

[11] R. Setiadi, C. Suhery, and R. Hidayati, "SISTEM PENDUKUNG KEPUTUSAN EVALUASI PEMILIHAN PEMENANG DALAM PELELANGAN PENGADAAN ASET JALAN DAN JEMBATAN MENGGUNAKAN METODE WEIGHTED PRODUCT (WP) BERBASIS WEB (Studi Kasus: Dinas Pekerjaan Umum Provinsi Kalimantan Barat)," Coding J. Komput. dan Apl., vol. 7, no. 03.

[12] U. Ependi, A. Putra, and F. Panjaitan, "Evaluasi tingkat kebergunaan aplikasi Administrasi Penduduk menggunakan teknik System Usability Scale," Regist. J. Ilm. Teknol. Sist. Inf., vol. 5, no. 1, pp. 63-76, 2019.

[13] S. Suyanto and U. Ependi, "Pengujian Usability dengan Teknik System Usability Scale pada Test Engine Try Out Sertifikasi," MATRIK $J$. Manajemen, Tek. Inform. dan Rekayasa Komput., vol. 19, no. 1, pp. $62-69,2019$.

[14] R. N. Hays, A. Sugiyarta, and D. E. Winungkas, "Aplikasi Inventory Terintegrasi Order System Konsumen Pada Oto Bento Perumnas Cilegon Menggunakan Metode Waterfall," ProTekInfo (Pengembangan Ris. dan Obs. Tek. Inform., vol. 5, 2018.

[15] F. Syakti, "Sistem Informasi Geografis Penderita Malaria pada Kelurahan Cereme Taba Kota Lubuklinggau," Digit. Zo. J. Teknol. Inf. dan Komun., vol. 10, no. 2, pp. 178-188, 2019.

[16] R. S. Presman, "Rekayasa Perangkat Lunak Pendekatan Praktisi Edisi 7 (Buku Satu)," Penerjemah Adi Nughroho, Georg. John Leopold Nikijuluw, theresia Herlina Rachadiani dan Ike Kurniawati Witaya. Yogyakarta Penerbit Andi, 2012.

[17] F. Fatoni and D. Irawan, "Implementasi Metode Extreme Programming dalam Pengembangan Sistem Informasi Izin Produk Makanan," $J$. Sisfokom (Sistem Inf. dan Komputer), vol. 8, no. 2, pp. 159-164, 2019.

[18] A. Penira, A. Zahara, M. Ramadhani, and M. L. Amin, "ANALISA DAN PERANCANGAN SISTEM E-CLAIM PADA PT ASURANSI JIWA SYARIAH BUMIPUTERA CABANG MEDAN," J. Tek. Inform. Kaputama, vol. 4, no. 1, 2020.

[19] S. S. Harahap, "Sistem Pendukung Keputusan Penyetujuan Kartu Kredit Pada PT. Bank Rakyat Indonesia Dengan Menggunakan Metode Simple Additive Weighting (SAW)," J. Sist. Inf. dan Ilmu Koтput. Prima (JUSIKOM PRIMA), vol. 2, no. 2, pp. 1-7, 2019. 